\title{
Performing gender in Chinese cinema
}

\section{Hongwei Bao}

\section{Publication information:}

Bao, Hongwei (2018) 'Performing Gender in Chinese Cinema', in Jieyu Liu and Junko Yamashita (eds) Routledge Handbook of Gender in East Asia. London: Routledge.

\begin{abstract}
:
In this chapter, I trace a brief genealogy of how Chinese cinema engages with the issue of gender. In doing so, I examine how gender has been represented and constructed through the cinematic apparatus in different eras of modern Chinese history. I suggest that filmic constructions of gender have participated in modern China's nation building project, and furthermore, they have articulated different imaginations of Chinese modernity. Indeed, the representation of gender in Chinese cinema has been closely intertwined with colonial, socialist and postsocialist imaginations of Chinese modernity and these imaginations have shaped modern and contemporary China. In other words, films not only teach people how to be women and men by providing role models and presenting lifestyle guides; they also inspire people to feel 'Chinese' and 'modern'. This chapter is divided into two sections, which deal, respectively, with the representation of women and men in Chinese cinema. I use an 'archetypical' approach (Frye 2001), that is, identifying key tropes, representative figures and recurring narrative patterns, in organising my discussion. In the first section, 'Women in Chinese Cinema', I draw on film critic Dai Jinhua's (2002) categorisation of Qin Xianglian, Hua Mulan and Nora figures as archetypes for modern Chinese women in discussing dominant tropes in the cinematic representation of women. In the second section, 'Men in Chinese Cinema', I draw comparisons between traditional Chinese opera's 'role types' (hangdang) and the cinematic representation of men. Such an innovative approach aptly recognises the close connections between various forms of Chinese art and media, theatre and cinema in this case, as both shaped by Chinese histories and cultural traditions and thus mutually constitutive.
\end{abstract}


Ever since film was introduced to China in 1896, cinema has played an important role in building a modern nation and constructing gender in the People's Republic of China (Lu 1997). ${ }^{1}$ The first Chinese film, Dingjun Mountain (Dingjun shan) made by Ren Jingfeng in 1905, features a Peking Opera performance of the famous laosheng (senior male role) actor Tan Xinpei, cast in the role of a national hero at a time of national crisis. The first feature film, The Difficult Couple (Nanfu nanqi) made by Zheng Zhengqiu in 1913, is a drama that portrays the dilemmas faced by a man and a woman when being forced by their respective families to enter into an arranged marriage. Both films place the nation at the core of the cinematic narrative: a national hero and a family in a nation torn by the tensions between tradition and modernity; they also offer various types of role models for women and men in a modern time. Indeed, from the outset of Chinese cinema, films have partaken in the nation-building project which centres around a modern construction of women and men.

In this chapter, I trace a brief genealogy of how Chinese cinema engages with the issue of gender. In doing so, I examine how gender has been represented and constructed through the cinematic apparatus in different eras of modern Chinese history. I suggest that filmic constructions of gender have participated in modern China's nation-building project, and furthermore, they have articulated different imaginations of Chinese modernity. Indeed, the representation of gender in Chinese cinema has been closely intertwined with colonial, socialist and postsocialist imaginations of Chinese modernity which have shaped modern and contemporary China. In other words, films not only teach people how to be women and men by providing role models and presenting lifestyle guides; they also inspire people to feel 'Chinese' and 'modern'.

This chapter is divided into two sections, which deal, respectively, with the representation of women and men in Chinese cinema. I use an 'archetypical' approach (Frye 2001), that is, identifying key tropes, representative figures and recurring narrative patterns, in organising my discussion. In the first section, 'Women in Chinese Cinema', I draw on film critic Dai Jinhua's (2002) categorisation of Qin Xianglian, Hua Mulan and Nora figures as archetypes for modern Chinese women in discussing dominant tropes in the cinematic representation of women. In the second section, 'Men in Chinese Cinema', I draw comparisons between traditional Chinese 
opera's 'role types' (hangdang) and the cinematic representation of men. Such an innovative approach aptly recognises the close connections between various forms of Chinese art and media, including theatre and cinema, as both are shaped by Chinese histories and cultural traditions and are mutually constitutive. Due to the limitation of space, my discussions are confined to films produced in the People's Republic of China, i.e. Mainland China, and my choice of films is necessarily selective and subjective. However, I acknowledge the transnational and plural nature of Chinese cinemas and the cultural specificity of each geographical entity in the Chinese-speaking world. It is in the context of the transnationalism and globalisation that my discussion of gender and cinema is situated (Lu 1997; Zhang 2004, 2010, 2012; Berry and Farquhar 2006; Lim and Ward 2011; Rojas and Chow 2013; Yue and Khoo 2014; Chan and Wills 2016).

\section{Qin Xianglian, Hua Mulan and Nora: women in Chinese cinema}

Women have always been present in the century-long history of Chinese cinema. However, despite the heterogeneity of female images, women can also be seen as quite similar, stereotypical and often problematic in cinematic representations as a result of lingering cultural traditions and cinematic conventions. In the process, several archetypes, or tropes, of Chinese women have emerged on the Chinese screen, which film critic Dai Jinhua (2002) categorises as Qin Xianglian, Hua Mulan and Nora. In this section, I use Dai's categorisation to discuss the politics of representing women in Chinese cinema. I also examine the issue of 'male gaze' (Mulvey 1975) popular in the study of cinema and raise the question of female authorship, i.e. women filmmakers in China.

Qin Xianglian is a fictional character in classical Chinese fiction and opera. She is a Song Dynasty woman betrayed by her husband, who not only marries another woman but also tries to kill Qin to cover up his past. Qin, in Chinese culture, represents powerless Chinese women suffering in an unjust social system, which usually takes the form of a patriarchal family or a feudal or capitalist society. It is important to note that the Qin Xianglian figure is usually portrayed by male writers and filmmakers, primarily during the May Fourth era and the Mao era, to expose the darkness of the old society and to articulate the leftist intellectuals' longing for a new and more egalitarian society. The 'male guilt' is thus at the centre of the Qin Xianglian's 
narrative and the 'weak woman' figure is often seen as an allegory of a weak nation waiting to be protected and saved by strong male figures. The Qin Xianglian type of women has appeared in numerous films, including the protagonist Sister Ruan in Wu Yonggang's 1934 film The Goddess (Shennü) and Sister Xianglin in Sang Hu's 1956 film New Year Sacrifice (Zhufu) adapted from Lu Xun's short story. While it is commendable to represent subaltern figures such as prostitutes and poor peasant women on the Chinese screen, both types of women are portrayed as subjects of public sympathy in order to awaken the critical consciousness of the audience, a technique often deployed by left-wing filmmakers in the Republican and the Mao eras. Although the Qin Xianglian figure is powerful in revealing women's subjugated position in family and society, it is insufficient for the needs and demands of the communist revolutionary hegemony as she is often seen as lacking in revolutionary consciousness. In the Mao era, a heroic female figure appeared on the Chinese screen. She is strong, determined, independent and politically conscious. She may have suffered from the injustices of the 'old society'; she has now been empowered and can achieve anything and everything once she has gained revolutionary consciousness. She is usually dressed in gender-neutral clothes and cares little about her physical appearance. She does not have sexual desires. Her gender and sexual subjectivities disappear as soon as she gains political consciousness. She is sometimes referred to as an 'iron girl' (tie gu'niang) or Hua Mulan. ${ }^{2}$ Hua Mulan is the second archetype for Chinese women in Chinese cinema. The figure draws on the Chinese folk tale of Hua Mulan, who disguises herself as a man and fights courageously for the nation on behalf of her elderly and ill father. In the Mao era, the Hua Mulan figure is usually represented as a poor girl who joins the Red Army and who devotes herself to the communist revolution. Such characters in Chinese films include Lin Daojing in Cui Wei and Chen Huaikai’s 1959 film Song of Youth (Qinchun zhi ge) and Wu Qionghua in Xie Jin's 1961 film The Red Detachment of Women (Hongse niangzijun).

The Hua Mulan figure was successful in constructing a revolutionary hegemony and in projecting a strong and independent woman's image on screen. It reflects a rise in women's status in China during the Mao era through a series of top-down reforms to elevate women's social status, crystallised in Mao's famous saying 'the times are different; men and women are now all the same' (quoted in Dai 2002: 99). Perhaps 'the same' is where the problem lies: instead of improving women's social status through actively constructing women's subjectivity, the 
Maoist discourse on gender equality 'erases' women's (and men's) gender and subsumes gender under the category of class. Political subjectivity thus replaces gendered subjectivity; and 'gender equality' becomes 'gender erasure' in service of politics (Yang 1999). Moreover, the representation of 'liberated women' and 'iron girls' in cinema is deeply problematic: women are usually enlightened and guided by an authoritative male figure embodying the spirit of the Chinese revolution and national salvation. For instance, Lu Jiachuan and Jiang Hua in Song of Youth and Hong Changqing in The Red Detachment of Women play a crucial role in empowering Lin Daojing and Wu Qionghua. In this way, in socialist cinema, 'a scattered and de-centred male power was replaced by a patriarchal form appearing in the form of the Nation, which once again became Woman's almighty overlord' (Dai 2002: 112). An equally patriarchal hegemony, the amalgamation between the communist revolution and the nation, has been established. Women's liberation is far from being guaranteed in this picture.

The third archetype of women on Chinese screen is Nora, a figure from Henrik Ibsen's play $A$ Doll's House. Nora is a brave and intelligent young woman who resolutely chooses to leave her husband and children to pursue her own independence after discovering her status as a 'doll', a plaything for men in a patriarchal family and society. Ibsen's play A Doll's House was translated and performed in China during the May Fourth era and has triggered intense intellectual debates about female subjectivity and women's liberation ever since. The May Fourth 'new woman' (xin nüxing) figure is largely modelled on the Nora type of figure. Chinese writer Lu Xun even gave a talk to a women's college in Beijing in 1923 reflecting on what happens after Nora walks out (Barlow 2004: 121). Lu Xun did not offer any practical solution for young women such as Nora, but at the core of his talk was the complex relationship between historical, social and material conditions and women's liberation. Chinese screen has no shortage of single and courageous young women who leave patriarchal families and walk into society. Their stories in the public life are, however, not always happy and bright. From socialist to postsocialist Chinese cinema, the Nora figures abound, from Xie Fang's characters in the socialist cinema to Gong Li's characters in many of Zhang Yimou's films.

Chris Berry (2013), and Berry and Farquhar (2006) argue that instead of the traditional image of the mother as a reincarnation of the nation seen in many world cinemas, the unmarried daughter 
figure, or a young single woman in study or at work, provides a role model for Chinese modernity and she is often represented as independent, hardworking, a figure out of a domestic sphere and into the public sphere. Berry also detects a deep ambivalence in the contemporary cinematic representation of Nora-type figures, as represented in the cinematic techniques of 'splitting and doubling', that is, a halt in the film narrative in deadlock or the introduction of a parallel narrative with a different person, which seem to offer an imaginary solution to the unstoppable imperative of 'moving forward' and at the same time express the impossibility of such an imaginary solution. Berry reads the 'splitting and doubling' technique as a symptom of the crisis of postsocialist modernity in China, i.e. a 'symptom of compulsory progress under conditions of Chinese neoliberalism, which combines a one-party authoritarian political system with a market economy structured around growth' (2013: 14). This insight is useful, as it accurately attends to the 'political unconscious' (Jameson 1983) of cinematic narratives and techniques in specific historical contexts. However, it has not sufficiently explained why female characters, instead of male characters, are chosen for the 'splitting and doubling' type of cinematic techniques on screen. The gendered nature of postsocialist modernity, in which women are placed at a more disadvantageous position in a market economy, may be key to the answer. Seen all together, considering the dominance of the realistic mode in Chinese cinema throughout the twentieth century, the three archetypes of women in Chinese cinema bespeak the unequal status of women to men in Chinese society. In the Republican left-wing cinema, women were seen as suffering victims that embody the pains and traumas of the nation, waiting to be rescued or enlightened by men. In the socialist cinema of the Mao era, women were represented as strong and independent characters; and yet, they sacrificed their gendered subjectivity for a political subjectivity and for the nation. In the postsocialist era, women are 'resexualised' for the male gaze from both China and abroad. Although the sexualisation of women's bodies is not new in Chinese cinema, it manifests distinct features and sensibilities in a globalised market economy. Their newly acquired gendered subjectivity has quickly been taken advantage of by capitalism in articulating gender with individualism, free choice and distinctive consumption.

The works of the Fifth-Generation filmmakers, a group of filmmakers whose films represent a particularly creative moment in Chinese cinema in the 1980s and 1990s, including Zhang Yimou and Chen Kaige, garnered fame and prestige for Chinese films at major international film 
festivals. Yet, these filmmakers, mostly male, often present an image of primitive, unchanging and rural China with oppressed women for the orientalist gaze of the international audience. Shuqin Cui suggests that these male filmmakers 'look to the female body as a site for the projection of oppressed national experiences and as a sign for castrated male sexuality' (2012: 499). While Chen Kaige's early auteur-styled works often render women invisible or silent in his obsessions with an essentialised notion of Chinese culture, such as Yellow Earth (Huang tudi, dir. Chen Kaige, 1984), King of Children (Haizi wang, dir. Chen Kaige, 1987) and Life on a String (Bianzou bianchang, 1991), his later big-budget films such as Temptress Moon (Fengyue, 1996), The Emperor and the Assassin (Jingke ci qinwang, 1999), The Promise (Wuji, 2005) and Forever Enthralled (Mei Lanfang, 2008) often place women as a sexualised subject and in the male gaze for a commercialised film industry.

Women are often at the centre of Zhang Yimou's films, epitomised by the fact that their lead actresses are usually national and international stars such as Gong Li, Maggie Cheung and Zhang Ziyi. Zhang's early films usually depict 'women in an iron house' (Dai 2002: 132), or desire women trapped in a repressive traditional Confucian patriarchal society, such as Ju Dou in Judou (Judou, dir. Zhang Yimou, 1990) and Songlian in Raise the Red lantern (Dahong denglong gaogaogua, dir. Zhang Yimou, 1991). Zhang's style has changed in some of his later works by adopting a documentary style to reflect contemporary life, such as Not One Less (Yige ye buneng shao, 1999) and The Story of Qiu Ju (Qiu Ju da guansi, 1992), and his blockbuster style martial arts films including Hero (Yingxiong, 2002) and Curse of the Golden Flower (Mancheng jindai huangjin jia, 2006). The critique of his films as being complicit with orientalism and the male gaze continues:

by interweaving the focalisation on feminine suffering with the advanced technologies of cinematography and film editing, Zhang has reignited the place of woman in mainland filmmaking with an insuppressible power of objectification, in full responsiveness to the libidinal tendencies of a postmodern, corporatist globalism with its preference for glitzy, flawless packaging.

(Chow 2013: 495) 
Chinese women have thus become a sign for the West's orientalist imagination of China and for China's Fifth-Generation filmmakers' self-writing, or 'autoethnography', in the postcolonial age (Chow 1995). In the obsession with 'returning to nature' by privileging landscape, rural life and oppressed women in cinematic representation, Chinese male filmmakers have expressed 'primitive passions' for a no-longer-existing but re-imagined China, and women became the embodiment of such a cultural fantasy (Chow 1995: 42).

From the 1990s onwards, with the development of the market economy and the commercialisation of China's film industry, women's bodies have been increasingly sexualised, objectified and commodified on screen, even under the gaze of the avant-garde, or SixthGeneration, filmmakers who concern themselves with the margins of society (Donald 1998; 2008). Such films include Zhang Yuan’s Beijing Bastards (Beijing zazhong, 1993), Wang Xiaoshuai's The Days (Dongchun de rizi, 1993), He Jianjun's Postman (Youchai, 1995), Lu Xuechang's The Making of Steel (Zhangda chengren, 1998), Lou Ye's Suzhou River (Suzhou he, 2000) and Jia Zhangke's The World (Shijie, 2004). Despite their stylistic and aesthetic innovations, many of these Sixth-Generation filmmakers, most of whom are male, present female bodies not only to the voyeuristic gaze of a domestic audience, but the orientalist gaze of an international audience as well. Women in these films still do not seem to have their voices, desires and agencies. As Stephanie Hemelryk Donald comments, in the postsocialist economic reform and the corresponding restructuring of the social class, the place of the feminine is 'contingent on masculine desire' (Donald 2008: 477).

It is a good time to recall what film studies have to say about the gendered nature of commercial cinema. Perhaps one of the best-known essays on the cinematic representation of women in film studies is Laura Mulvey's (1975) essay on the 'male gaze', which offers a psychoanalytic analysis of how women were subjected to the voyeuristic and objectifying male gaze in classical Hollywood cinema and were therefore represented as sexualised and submissive. In Chinese film studies, the 'male gaze' model has been both challenged and reaffirmed. Chris Berry (1985) suggests that the viewing subject in China's socialist realist cinema is 'not engaged libidinally but epistemophically in a position of heightened knowledge that is not necessarily gendered' 
(quoted in Berry and Farquhar 2006: 111). This insight is useful in the examination of socialist realistic films such as Li Shuangshuang (dir. Ren Lu, 1962), in which the female protagonist is often seen from the vantage point of an epistemic regime with a higher intellectual and moral order, the communist party-state and its ideological apparatus. However, whether we can generalise the statement to the analysis of films of different genres and from different historical periods is questionable. For example, the way how Ruan Lingyu's admirer looks at Ruan's legs in The New Woman (1935) is undoubtedly sexualising and objectifying for women (Berry and Farquhar 2006: 120). It turns out that the gazes from the bourgeois class or 'class enemies' are libidinal, whereas the gazes between socialist comrades committed to the communist revolution are not. 'Gendered gaze' becomes a vehicle to distinguish 'us' from 'them', 'insider' and 'outsider', 'friends' from 'enemy', 'Han majority' from 'ethnic minorities' and 'Chinese' from 'Western', and is thus deeply political.

One of the factors that render the 'male gaze' theory potentially problematic in the Chinese context has to do with the fact that there is no shortage of female filmmakers in China's film industry. Indeed, women have always been present, not only as actors but as directors and writers, since the establishment of China's film industry (Berry 1989; Dai 2002; Cui 2003; Wang 2011). In 1925, a family melodrama, An Orphan's Cry (Guchu beiqing), was made by female director Xie Caizhen; and in the same year, Pu Shuqing's screen play Cupid's Puppets (Aiqing de wan'ou) was adapted to film. In the Mao era, female filmmakers Wang Ping, Wang Shaoyan and Dong Kena received enormous institutional support and great prestige from the state. Some of the films they made, including The Story of Liubao Village (Liubao de gushi, dir. Wang Ping, 1957), Red Coral (Hong shanhu, dir. Wang Shaoyan, 1961) and Small Grass Grows on a Kunlun Mountain (Kunlun shanshang yikecao, dir. Dong Kena, 1962), have become classics of socialist cinema. These films were mostly revolutionary films, with no obvious gendered imprint from their directors.

The situation started to change in the 1970s and 1980s, when there was a proliferation of women filmmakers, and some of their films started to display a distinct 'female consciousness'. The use of female perspective in narrating women's experiences and desires in Hu Mei's 1986 film Army Nurse (Nü'er Lou) is a good example. In the decade following the fall of the 'Gang of Four' in 
1976, there were over thirty fully fledged women directors making feature films (Berry 1989). Out of the fifteen Ministry of Culture Outstanding Film Awards for 1985, seven were made by women (Berry 1989). These were world-leading figures in terms of gender ratio in the film industry, an often forgotten past in the history of world cinema. Importantly, some of these films the female filmmakers have made display a strong sense of female subjectivity, through gendered modes of enunciation such as the use of subjective voice-over techniques and a subjective style of story-telling (Berry 1989). These films include Sacrificed Youth (Qingchun ji, dir. Zhang Nuanxin, 1985), Army Nurse (Nü'er lou, dir. Hu Mei, 1986) and The Season for Love (Lian'ai de jijie, dir. Urshana, 1986). Dai Jinhua (2002: 153) regards Huang Shuqin’s 1987 film, Woman, Demon, Human (Ren, gui, qing) as the first 'feminist film' in China because the distinct gender consciousness and feminist sensibility manifested in the film. In these films, women are the centre and subject of the narrative; at the same time, 'a profoundly plaintive and refined tone became central to the film's cinematic mode' (Dai 2002: 142).

The boom of 'women's cinema' in the 1970s and 1980s did not last long. From the 1990s and into the new millennium, 'women's cinema' has gradually disappeared or gone unnoticed from China's film industry. Meanwhile, China's film industry also underwent dramatic transformations under commercialisation and globalisation. Competing with Hollywood for audiences and box office revenues, China's film industry has developed a craze for domestic blockbusters (dapian) or transnational co-productions, thus effectively marginalising and eliminating small and independent productions. Independent Chinese films have managed to survive despite financial difficulty and government censorship. The introduction of light, portable and affordable digital video cameras into China has not only ushered in China's 'New Documentary Movement' (Berry, Lü and Rofel 2010; Robinson 2013) but also produced an increasing number of female filmmakers. From the early 2000s, many women have started to use digital video cameras to document their lives and the society they live in. Female documentarians such as Feng Yan, Shi Tou and Ai Xiaoming have turned their attention to marginalised social groups and issues such as the relocation of people for the Three Gorges Project, the development of China's ethnic minority regions, a self-organised protest in a Chinese village and HIV/AIDS infections in central China. They have also self-consciously inserted their female subjectivity into their films. These films include: Bing 'ai (Bing'ai, dir. Feng 
Yan, 2007), Women 50 Minutes (Nüren wushi fenzhong, dir. Shitou, 2006), Taishi Village (Taishi cun, dir. Ai Xiaoming and Hu Jie, 2005) and The Central Plain (Zhongyuan jishi, dir. Ai Xiaoming and Hu Jie, 2006). In Shi Tou's film Women 50 Minutes, for example, Shi Tou and her partner Ming Ming appear on the screen and celebrate same-sex intimacy between women; the filmmaker even inserts her own comments on Chinese society in subtitles or as voice-over (Bao 2000). At the margins of a highly commercialised film industry, female filmmakers have been articulating their social concerns with their female subjectivity. They see filmmaking as a way of engaging with society and making social changes. Feminism has never been so politically pertinent in Chinese cinema.

I shall end this section with discussions of two recent Chinese films, Angles Wear White (Jia nianhua, dir. Vivian Qu, 2017) and Girls Always Happy (Rouqing shi, dir. Yang Mingming, 2018). Both films were directed by female filmmakers, and both put women's experiences at the centre of the film narratives: Angles Wear White explores sensitive issues of sexual harassment and child abuse in a male-dominated society; Girls Always Happy asks the critical question of whether, and how, women can afford to have a room of their own in order to pursue their dreams of becoming writers without being dependent on men. More importantly, there is a strong sense of female subjectivity in the film narratives and in the mise-en-scene of the films: in Angles Wear White, the camera mostly shoots the statue of Marilyn Monroe's famous upskirt pose from below, indicating sexualisation of women's bodies under the 'male gaze'. Like Vivian Qu and Yang Mingming, an increasing number of young female filmmakers have started to make their own films about women's experiences and with a strong female consciousness. We expect to see more complex and diverse representations of women on the Chinese screen in the future.

\section{The 'role types': men in Chinese cinema}

In this section, I will draw on a few 'role types' commonly used in Peking Opera, including sheng (the male role), dan (the female role, or male-to-female crossdressing role), jing (the painted face role) and chou (the clown role) to discuss the representation of men in Chinese cinema. This may seem an unconventional approach that risks to blur the boundary between cinema and theatre, but I believe that the approach has its own merits and can yield valuable insights. This approach recognises the close relationship between theatre and cinema in the 
Chinese context, as both are shaped by Chinese histories and cultural traditions and both inform each other in the twentieth-century China. The crucial role played by classical Chinese opera in the development of Chinese cinema has been well documented: Chris Berry and Mary Farquhar (2006), for example, pinpoint Chinese cinema's origin and roots in classical opera, as demonstrated by the term yingxi ('shadow opera'), an earlier way to refer to cinema in Chinese language. Moreover, they identify the 'operatic mode' as a distinctive and enduring mode of Chinese cinema. A 'role type' approach may risk simplifying and stereotyping male representations as well as downplaying historical ruptures and discontinuities.However, for the purpose of this chapter, it delineates some recurring features in filmic representations as well as identifies continuities and ruptures in the constructions of masculinity in a historically informed and context-specific manner.

Before we move on to discover the continuity of male role types across artistic medium and genre between classical Chinese opera and Chinese cinema, it is useful to review some existing scholarship on Chinese masculinities. In his ground-breaking book Theorising Chinese Masculinity, Kam Louie (2002) offers a culturally specific model of conceptualising dominant models of masculinity in Chinese history through the wen/wu (literary/martial) dyad. Geng Song's 2004 study of the image of the talented but physically fragile scholar (caizi) in late imperial Chinese literature emphasises the politicised, hierarchical and fluid ying/yang framework in constructing gender relations in China and in privileging wen (literary) masculinity over $w u$ (martial) masculinity. It is easy to see wen/wu and yin/yang as two distinct interpretative frameworks; they are in fact quite compatible with and even complementary to each other. After all, it is the dynamic flow of yin and yang that constitutes the wen and wu attributes; and it is class relations and social conditions that try to pin down the fluid yin/yang configurations and name them wen and $w u$. Wen and $w u$ can therefore be seen as 'hegemonic masculinities' (Connell 2005) over a wide spectrum of multiple and contingent gendered expressions for men in ancient China. The wen/wu-yin/yang interaction nicely underscores an indigenous understanding of the male gender that is socially constructed rather than biologically determined, becoming rather than being. 
Despite Louie's and Song's acute attention to the historical and cultural specificity of the model and the persistence of historically informed cultural expressions, the wen/wu-yin/yang model cannot effectively account for the changing forms and expressions of gender in modern times, after the Western epistemology of gender and human subjectivity entered China and when globalisation started to exert a powerful influence on the reconfigurations of gender relations. Geng Song and Derek Hird (2013), Hird and Song (2018) and Kam’s (2014) recent works examine contemporary expressions of masculinities in a globalising China, shaped by individualism, consumerism, neoliberalism, socialist values, state ideology, media and popular culture, as well as an enduring discourse about cultural traditions.

In Peking Opera, a typical male role is called sheng and it is usually divided into five sub-types: laosheng ('old man'), xiaosheng ('young man'), hongsheng ('red-faced man'; red face symbolises loyalty and integrity), wusheng ('martial arts man') and wawa sheng ('boys') (Riley 1997). Age and special traits (red face or martial arts competence) are usually the determining factors in the categorisation of these characters. The wen/wu-yin/yang dynamics is at work here: senior, righteous and martial men are believed to possess more yang; and younger and literati men are believed to possess more yin. What demarcates laosheng and xiaosheng is not simply age, but also the possession of more literary or martial skills, intelligence, experience, social sophistication and, above all, more yang elements. Hierarchies are produced along class lines and divided by scenes or 'fields' (Bourdieu 1984): martial (wu) skills are valued over literary skills (wen) in martial arts and battle scenes, and literary skills (wen) over martial (wu) skills in literary and court scenes. Eventually, it is a good combination and an equilibrium of both wen and wu that is key to a man's success and that marks an ideal masculinity.

Zhang Yimou's 2004 martial arts epic Hero offers a good example of how masculinity is imagined in relation to the construction of a Chinese identity in a commercial blockbuster (Berry and Farquhar 2006; Louie 2008). Louie (2008: 137) argues that the film's domestic box office success and its international controversy can be attributed to its engagement with 'the ancient and well established wen-wu masculine ideals at a mythological level'. Indeed, 'what is an ideal Chinese man' or 'who is the true Chinese hero' seems a key question for the film to address. Although the assassin Nameless is an outstanding martial arts $(w u)$ expert who has both the 
determination and capability of killing the King of Qin, it is eventually the king's possession of wen, that is, his intellectual capacity to see a big picture and, furthermore, his perfect embodiment of both wen and $w u$, that makes him the true hero 'under the Heaven' (tianxia). The film thus expresses "the primeval desire to be a "real man" involves the acquisition and understanding of a spiritual reunion of wen and wu' (Louie 2008: 143); it also demonstrates the primacy of wen over $w u$ in a balanced integration of both in a traditional elite Chinese culture. The king's success seems to make sense if we look at the film through the lens of Peking Opera role types: the assassin Nameless assumes a wusheng role, while the king assumes a laosheng role: the determining factors of age and social position, as demarcated by traditional Chinese codes of social relations, require that a young man in a lower social rank submits to an older man in a higher social position.

Chris Berry and Mary Farquhar's (2006) discussion of male codes is helpful in understanding the male-male relations in cinematic representation. Berry and Farquhar discern three types of codes that govern male-male relations in a Confucian culture: 'filiality (xiao), brotherhood (yi) and loyalty (zhong)' (p. 138). A Confucian man is often required to be 'respectful to the father, faithful to the brother and loyal to the king/emperor/nation'; and perform his duties in the order of xiushen, qijia, zhiguo, ping tianxia ('one must cultivate oneself morally before proceeding to establish order within the family, the state, and thereafter universally') (quoted in Davis 2009: 58). Stanley Kwan's (1996) film about gender in Chinese cinema also identifies 'looking for father, finding older brother' as a key theme in Chinese cinema. Kwan emphasises the role of the fatherly figure and the brotherhood amongst men to be of paramount importance for men in Chinese cinema. The subjugation and even sacrifice of the individual to a fatherly figure or a greater cause, be it a king, an emperor, a nation or a revolution cause, is common to the representation of men, and this is usually where state power and patriarchal ideology are at work to produce cinematic codes.

In socialist cinema, a man often sees the ideal of communist revolution before himself and is prepared to sacrifice himself for the ideal. The relationship between the individual and the nation is problematised in postsocialist cinema. However, the fatherly figure has not disappeared completely. In many state-funded patriotic 'main melody' (zhuxuanlï) films, the Party and the 
nation, and the combination of the two, are still represented as authoritative fatherly figures for individuals to subjugate themselves to. Rebellions do occur in the films made by the FifthGeneration filmmakers: for example, Nameless carefully designed plans to assassinate the king in Hero, or Qiu Ju's relentless efforts to sue the village chief who refuses to apologise for his wrongdoings. These rebellions mostly fail or end with an ideologically ambivalent tone, enough to throw the act of rebellion into doubt. The assassin gives up his assassination attempt and is prepared to die, deeply convinced that the king's military expansion will benefit all people 'under Heaven'. When Qiu Ju finds out, much to her astonishment, that the village chief is arrested by the police because of her successful lawsuit, her original motive of seeking justice through law is immediately put into question. Berry and Farquhar (2006: 144) sum up the patriarchal and patriotic ideologies in some of Zhang Yimou's films in a narrative formula when he compares The Story of Qiu Ju with Hero: 'In both films, an ultimate albeit problematic lawgiver defines the nation through state legal codes. In both films, state law conflicts with various individual sense of social justice. In both, the state wins'. The obsession with a fatherly figure, in the form of an emperor, a village chief or a patriarch in many Fifth-Generation films, is thus deeply problematic and ideologically conservative; it encourages a conformist approach to a patriarchal state and official ideologies. Many filmmakers, in their relentless pursuit of critical historical and cultural reflection through cinema, have unexpectedly ended up being complicit with the state.

In many socialist and Fifth-Generation films, although intimacy between men and women is largely absent, intimacy between men is, however, commonplace. This should not be understood as homosexuality but homosociality, i.e. male bonding, brotherhood, friendship or camaraderie between heterosexual men (Sedgwick 1985). This often raises the issue of 'homosexual subtext' for a queer spectatorship (Bao 2018). For example, Chen Kaige's 1986 film The Big Parade (Da Yuebing) depicts the life of soldiers in a military barrack; its bold representation of male nudity and the mutual care between fellow male soldiers are usually read by gay audiences as 'queer subtext' in a 'celluloid closet' (Lim 2006).

This brings us to the second role type in Peking Opera, dan (the female role, or the male-tofemale crossdressing role), which offers another way for the representation of sex, sexuality and 
intimacy in a historical context where open representation of intimacy on screen is not possible. In Peking Opera and early cinema in the past, female roles were usually performed by men dressing up as women. Up to Li Minwei’s 1913 film Zhuangzi Tests His Wife (Zhuangzi shiqi), all female roles in Chinese cinema were performed by male actors dressed up as women (Fan and $\mathrm{Wu} 2012: 35)$. Although the practice of crossdressing for operatic performances was terminated during the socialist era, male-to-female crossdressing characters can still be seen in historical or contemporary dramas. For example, in Yang Yanjin's 1980 film Little Street (Xiaojie), the love between the male protagonist and the female protagonist is disguised as friendship between brother and sister when the female protagonist dresses herself as a man. This was largely because in the beginning years of the post-Mao era, open representation of love between men and women was difficult. Crossdressing thus provided a means to facilitate discussions of taboo topics such as love in an ascetic political context.

Transgender performance also offers a way for same-sex intimacy to be represented on the postsocialist Chinese screen. Chen Kaige's Palme d'Or award-winning film, Farewell, My Concubine (Bawang bieji, 1993), is a good example. Peking Opera actor Cheng Dieyi's love for his fellow actor, Duan Xiaolou, can only be articulated on the theatre stage and when he dons the costume of a concubine. Zhang Yuan's 1996 film East Palace, West Palace (Donggong xigong), is another example in case: the policeman Xiao Shi has to dress the homosexual figure Ah Lan up in women's clothes in order to express his own homosexual desire. Song Hwee Lim (2006) suggests that the expression of homosexual desire through crossdressing performance on theatre stage is not necessarily an identification of gay men with the feminine; rather, it offers queer desire a socially recognised and culturally specific way to articulate itself that would otherwise be impossible at the time. This also explains the proliferation of transgender performances in some of the queer documentaries in the early 2000s, including Miss Jinxing (Jinxing xiaojie, dir. Zhang Yuan, 2000), The Snake Boy (Shanghai nanhai, dir. Michelle Chen, 2002), Tangtang (Tangtang, dir. Zhang Haizi, 2004), Baobao (Baobao, dir. Han Tao, 2004), Meimei (Meimei, dir. Gao Tian, 2005), Xiang Pingli (Xiang Pingli, dir. Jiang Zhi, 2005), Beautiful Men (Renmian taohua, dir. Du Haibin, 2005), From Chrysalis to Butterfly (Diebian, dir. Wang Yiren, 2005) and Madame (Gu nainai, dir. Qiu Jiongjiong, 2009). There are complex reasons as to why crossdressing characters should become the privileged subject for queer representation at the 
time: apart from the subjects' confidence in coming out as performing artists, the voyeuristic gaze of the heterosexual-identified filmmakers and the audience often plays a role in representing the queer 'other' as exotic and erotic (Chao 2010; Robinson 2015; Bao 2018).

The painted face jing role in Chinese opera usually represents a prominent male character with striking looks, high social position and distinct personality. The character often appears as a male protagonist in Chinese cinema. In socialist cinema, the jing role is usually embodied by a politically oriented male figure, e.g. a respected Communist Party member such as the communist commissar Wang Ping in the film Dong Chunrui (dir. Wei Guo, 1955), Commissar Guo in the film The Muslim Detachment (Huimin zhidui, dir. Li Jun and Feng Yifu, 1959) and Hong Changqing in The Red Detachment of Women. He represents all the positive characteristics of a communist revolution. But the figure can be a villain too, as long as he has a strong and distinctive personality and is central to the narrative. Such a stereotypical representation of protagonists is often described as lianpuhua (face-typed), a term originating from the face painting tradition of Peking opera. In postsocialist cinema, such stereotypical characters are given more complexities and nuances, or even consciously resisted, with the popular belief that a person does not have to be perfect and that people all have their weaknesses. A call for the representation of 'real people' in 'real life' replaces the imperative to represent 'tall, grand and perfect' (gao, da, quan) characters in socialist cinema. Zhang Junzhao's 1984 film One and Eight (Yige yu bage) is seen as a path-breaking film in postsocialist cinema: instead of focusing on heroic figures and significant historical events, the film features the lives and experiences of some antiheroes, including criminals, gang members, deserting soldiers and accused traitors. The film signals a clear departure from the socialist realist films with an emphasis on humanism and personal conflicts of the ordinary people and ushers in a group of young and innovative filmmakers later known as the Fifth Generation filmmakers.

This brings us to the last role type in Chinese opera: chou (clown). While ugly and funny figures are commonplace in Chinese opera, they are also reincarnated in Chinese cinema, especially in comedies. They are usually 'little characters' (xiaorenwu); that is, ordinary people with weaknesses, in comparison with the heroic characters who are usually Communist Party members or main subjects of the revolution. The 'little characters' are constructed as both 
objects and potential subjects of the revolution. Because of their subordinate position in society, their revolutionary consciousness awaits to be awoken by the Party and the revolution. However, they cannot become the subject of history and revolution because of their deeply rooted weaknesses such as individualism, materialism, lack of courage and commitment to a grand social cause. The tenant characters in the 1949 film Crows and Sparrows (Wuya yu maque, dir. Zheng Junli, 149) are such 'little characters': the tenants can defeat a landlord temporarily when they act together but eventually, they are too weak and fickle to participate in a revolution. The character of Ah Q in The True Story of Ah Q (Ah Q zhengzhuan, dir. Fan Cen, 1981), based on Lu Xun's novella of the same title, is another example in case. Left-wing and socialist cinemas treat the 'little characters' in an ambivalent way: aiqi buxing, nuqi buzheng, i.e. to show sympathy for their misfortunes but to condemn them for their weaknesses at the same time. After the over-emphasis on 'perfect characters' in socialist cinema, the postsocialist Chinese screen turns to two different modes of male representation: 'looking for the real man' (xunzhao nanzihan) and 'little characters'. The discourse of 'looking for real men' emerged in the 1980s when there was a heightened anxiety about Chinese men's lack of masculinity as China opened up to the world (Zhong 2000). Characters such as Alain Delon, Ken Takakura and Arnold Schwarzenegger were seen as 'real men', while Chinese men were considered to be lacking in masculinity, as represented in 'root-seeking' (xungen) and 'scar' (shanghen) literary and film subgenres. Many of the Fourth-Generation films are devoted to the depiction of the individual and collective traumas from the Cultural Revolution. In this subgenre, men are usually represented as intellectuals persecuted during the Cultural Revolution; they are usually rich in knowledge and experience but weak in physicality, embodying the historical trauma they have experienced during the Cultural Revolution. Such films include Peng Ning's 1980 film The Sun and the Man (Taiyang he ren), Xie Jin's 1980 film The Legend of Tianyun Mountain (Tianyunshan chuanqi) and Wu Yigong's 1981 film Evening Rain (Bashan yeyu). The crisis of masculinity echoes 'both the modernist internalisation of Western gender standards as the universal norm and the rethinking of Communist gender ideology' (Song and Hird 2013: 9-10). The communist ideal of gender uniformity and collective subjectivity has now been replaced by a capitalist and consumerist inscription of gender based on assumed sexual differences. The West, or advanced capitalism, is seen as the ideal ground for gendered subjectivity and China's 
socialist past is repudiated on the grounds of its 'gender erasure' and suppression of 'human nature'.

In postsocialist Chinese cinema, cinematic representation of men is driven by 'a nationalist search for Chinese manhood' and 'the cultural politics of "remasculinising" Chinese culture in the post-Mao era' (Song and Hird 2013: 10). Jiang Wen, an actor cast in the role of the bandit hero in Zhang Yimou's Red Sorghum, became a star during that time because of the untamed, primitive and libidinal forms of masculinity he embodies. Jiang wrote and directed the 1994 film In the Heat of the Sun (Yangguang canlan de rizi); he also played the male protagonist Ma Xiaojun. In the film, the young, wild and unrestrained passion of the protagonist rewrites the memory of the Cultural Revolution on Chinese screen. The Cultural Revolution is not seen as an unspeakable national and generational trauma; it becomes a reconstructed historical space in which young men articulate their unrestrained masculinity in days of romance, wildness and abandonment.

The 'little characters' manifest a refusal to the 'grand narratives' and socialist ideals in the postsocialist era, when more and more people rue the insignificance of individuals at the wheel of history and the impossibility of making social changes. It also articulates a subaltern resistance, through the form of comedy, to state ideologies. Many of Feng Xiaogang's 'New Year Celebration Films' (hesuipian) follow the laughable stories of ordinary urbanites who struggle with life and love and who persevere in the market reform. These films include: The Dream Factory (Jiafang yifang, 1997), Be There or Square (Bujian busan, 1998), Sorry Baby (Meiwan meiliao, 1999), Sigh (Yisheng tanxi, 1999), Cell Phone (Shouji, 2003), A World without Thieves (Tianxia wuzei, 2004) and If You Are the One (Feicheng wurao, 2008). Ge You, the male lead for many of Feng's films, becomes a film star in spite, or perhaps because, of his ordinary looks. Ge is referred to as a chouxing ('ugly star'): 'embodying authenticity and effortless naturalness, Ge's chou [ugliness] is endowed with a conventional quality, enabling his character to contrast "offbeat" characters as well as voicing social anxieties on behalf of ordinary Chinese men' (Feng 2014: 136). 
Into the new millennium, when the Chinese economy has been deeply embedded in a global capitalist market and when Chinese cinema becomes more transnational, entrepreneurial masculinities have been valorised on the Chinese screen. The desirable men on screen are increasingly represented as well-educated business elites with material wealth, cultural capital and sexual appeal, such as the male boss in Go Lala Go! (Du Lala shengzhi ji, Xu Jinglei, 2010). These young entrepreneurs can be highly nationalistic as well: China's private entrepreneurs in American Dream in China (Zhongguo hehuoren, dir. Peter Chan, 2013) stand proudly and fight bravely against their American business counterparts with their deepy nationalist and patriotic sentiments. This demonstrates that developing a transnational form of business masculinity is not at odds with the endorsement of national identities; 'Chineseness' can also engender a hegemonic form of masculinity.

Transnational Chinese masculinities do not have to rely solely on material wealth and cultural capitals; they can be macho, aggressive and militaristic as well. In Wu Jing's 2017 blockbuster Wolf Warrior II (Zhan Lang 2), the protagonist Leng Feng, a former Chinese special forces operative, ventures into Africa to save his fiancée, the suffering African people and the international communities there from the dictatorship of African governments, a brutal civil war escalated by the intervention of Western powers, and a spreading epidemic. Promoted with the tagline 'anyone who offends China will be killed', the film represents a new type of hegemonic masculinity constructed by a rising 'great nation' and its global ambitions (Liu and Rofel 2018); it also testifies to the ambition of China's continuingly expanding film industries to 'go global' and to screen China's soft power worldwide ((Voci and Luo 2018).

At the same time, new forms of masculinity have emerged in China in response to consumer capitalism and social stratification (see Chapter 21 on masculinities in China); they include: dushi bailing ('a metropolitan white-collar man'), dushi yunan ('a metropolitan jade male'), huayang nanzi ('flower male'), nanshen ('a male god'), haigui nan ('a man who has returned from overseas'), zhainan ('a man who likes staying at home'), weisuo nan or wochuo nan ('an indecent man') and diaosi nan ('a mediocre man'). All these gender types have found their cultural representations in contemporary Chinese cinema. From the aforementioned analysis of representation of men on the Chinese screen, we can see that historically informed and culturally 
specific forms of masculinity are deeply embedded in contemporary cinema; they have also experienced mutations and transformations in a globalised world when modern and global forms of masculinity became emergent and subsequently dominant in cultural representations. Indeed, as Song and Hird (2013) aptly point out, masculinities in contemporary China, Chinese cinema included, are highly hybridised and diversified, and they must be examined in intersection with other identities such as class and nation and in the context of the dynamic interaction between the global and the local.

\section{Conclusion}

Teresa de Lauretis (1987) calls the cinema, along with other media and art forms, 'technologies of gender', in which gender is constructed through media and cultural representation. From the brief history of gendered representation in modern Chinese cinema outlined earlier, we have witnessed the processes in which hegemonic forms of gender are created, reinforced and challenged in cinematic forms, and they participate in the broader social discourses about how to be women and men in modern China. These images, tropes and narratives circulate in Chinese society and culture; they become part of the cultural memory and translate into ordinary people's everyday practices. They also delineate the tortuous processes in which politicians, intellectuals and ordinary Chinese imagine what China is and how the country can be modern. From a historical perspective, we can see that the representation of gender in Chinese cinema has been closely intertwined with the nation and national imaginations of modernity, be it colonial, socialist or postsocialist. The cinema has so far told people how to be women and men; it has also constructed what is Chinese and how to be modern in a globalised age. This type of construction is by no means linear, progressive, teleological and complete. Rather, it is full of gaps, ambiguities and contradictions. It points to the undecidability of gender and the incomplete project of Chinese modernity. A more urgent task is to critically reflect on and even challenge these hegemonic representations, thus opening up space for non-conforming, anti-hegemonic and democratic forms of gendered representations and social imaginaries.

By looking at the cinematic representations of gender through an 'archetypal' lens, we can appreciate the role that China's historical and cultural traditions play in shaping contemporary cultural representations. Indeed, historical forms of gender norms, values and images often exert 
strong influences on how gender is understood, practiced and represented in contemporary society. Any effort to cut off the historical link with a sole emphasis on modern, Western and global influences would be counterproductive, if not misleading. At the same time, we can also start to appreciate the cross-fertilisation and mutual influences between various cultural forms, including cinema, literature and classical Chinese theatre, in their historical development. By looking at the similarities and differences in how these cultural forms represent gender, we get a glimpse of the 'structures of feeling' (Williams 1961) at a particular time and in a particular society. This insight should encourage us to challenge rigid disciplinary boundaries: instead of seeing literary history, theatre history and film history as separate entities, it is useful to bring them together as different aspects of a cultural history, with its uneven and combined development, to examine how they shape gender norms and gendered representations in a longue dureé.

\section{References}

Bao, Hongwei (2010) 'In Search of Lesbian Continuum: Lesbian Public Space through Women 50 Minutes', in Mikako Iwatake (ed.) New Perspectives on Japan and China, Helsinki: University of Helsinki Renvall Institute for Area and Cultural Studies, 129-161. Bao, Hongwei (2018) 'From “Celluloid Comrades" to "Digital Video Activism": Queer Filmmaking in Postsocialist China', JOMEC Journal, 12: 82-100.

Barlow, Tani (2004) The Question of Women in Chinese Feminism, Durham, NC: Duke University Press.

Berry, Chris (1985) 'Sexual Difference and the Viewing Subject in Li Shuangshuang and The InLaws', in Chris Berry (ed.) Perspectives on Chinese Cinema, London: British Film Institute, 30-39.

Berry, Chris (1989) 'Chinese "Women's Cinema”, Camera Obscura, 18: 8-19.

Berry, Chris (2013) 'The Chinese Woman Doubled: An Essay in Memory of Paul Willemen (1944-2012)', Inter-Asia Cultural Studies, 14 (1): 14-25.

Berry, Chris and Mary Farquhar (2006) China on Screen: Cinema and Nation, New York: Columbia University Press.

Berry, Chris, Lü Xinyu and Lisa Rofel (eds) (2010) The New Chinese Documentary Film Movement: For the Public Record, Hong Kong: Hong Kong University Press. 
Bourdieu, Pierre (1984) Distinction: A Social Critique of the Judgment of Taste, London: Routledge.

Brownell, Susan and Jeffrey N. Wasserstrom (2002) Chinese Femininities, Chinese Masculinities: A Reader, Berkeley: University of California Press.

Chan, Felicia and Andy Wills (2016) Chinese Cinemas: International Perspectives, London: Routledge.

Chao, Shi-Yan (2010) 'Performing Gender, Performing Documentary in Postsocialist China', in Yau Ching (ed.) As Normal as Possible: Negotiating Sexuality and Gender in Mainland China and Hong Kong, Hong Kong: Hong Kong University Press, 151-176.

Chen, Yanru (2008) 'From Ideal Women to Women's Ideal: Evolution of the Female Image in Chinese Feature Films, 1949-2000', Asian Journal of Women's Studies, 14(3): 97-129.

Chow, Rey (1991) Woman and Chinese Modernity: The Politics of Reading between West and East, Minneapolis: University of Minnesota Press.

Chow, Rey (1995) Primitive Passions: Visuality, Sexuality, Ethnography, and Contemporary Chinese Cinema, New York: Columbia University Press.

Chow, Rey (2007) Sentimental Fabulations, Contemporary Chinese Films, New York: Columbia University Press.

Chow, Rey (2013) 'Fetish Power Unbound: A Small History of "Woman" in Chinese Cinema', in Carlos Rojas and Eileen Cheng-Yin Chow (eds.) The Oxford Handbook of Chinese Cinemas, Oxford: University of Oxford Press, 490-506.

Connell, Raewyn W. (2005) Masculinities, Berkeley: University of California Press.

Cui, Shuqin (2012) 'The Return of the Repressed: Masculinity and Sexuality Reconsidered', in Yingjin Zhang (ed.) A Companion to Chinese Cinema, Oxford: Wiley-Blackwell.

Cui, Shuqin (2013) Women through the Lens: Gender and Nation in a Century of Chinese Cinema, Honululu: University of Hawai'i Press.

Dai, Jinhua (2002) 'Gender and Narration: Women in Contemporary Chinese Film', in Jing Wang and Tani Barlow (eds.) Cinema and Desire: Feminist Marxism and Cultural Politics in the Works of Dai Jinhua, London: Verso, 99-151.

Davis, Gloria (2007) Worrying About China: The Language of Chinese Critical Enquiry, Cambridge, MA: Harvard University Press. 
De Lauretis, Teresa (1987) Technologies of Gender: Essays on Theory, Film and Fiction, Bloomington: Indiana University Press.

Donald, Stephanie Hemelryk (1998) 'Symptoms of Alienation: The Female Body in Recent Chinese Films', Continuum, 12 (1): 91-103.

Donald, Stephanie Hemelryk (2008) 'No Place for Young Women: Class, Gender, and Moral Hierarchies in Contemporary Chinese Films', Social Semiotics, 18 (4): 467-479.

Evans, Harriet (1997) Women and Sexuality in China, New York: Continuum.

Fan, Zhizhong and Wu Xinfeng (2012) Guoji chuanbo yujing xiade zhongguo dianying (Chinese Cinema in the Context of International Communication), Hangzhou: Zhejiang jiaxuechubanshe.

Feng, Lin (2014) “'I'm Ugly, But Gentle”: Performing “Little Character” in Post-Mao Chinese Comedies', Transnational Cinema, 5 (2): 127-140.

Frye, Northrop (2001) 'The Archetypes of Literature', in Vincent B. Leitch (ed.)The Norton Anthology: Theory and Criticism, New York: Norton, 1445-1457.

Gallagher, Mark (2018) Tony Leung Chiu-Wai, London: BFI and Palgrave Macmillan. Hird, Derek and Song Geng (2018) The Cosmopolitan Dream: Transnational Chinese Masculinities in A Global Age, Hong Kong: Hong Kong University Press.

Jameson, Fredric (1983) The Political Unconscious: Narrative as A Socially Symbolic Act, London: Routledge.

Ko, Dorothy and Wang Zheng (2007) Translating Feminisms in China, Malden, MA: Blackwell Publishing.

Kwan, Stanley (dir.) (1996) Yang \pm Yin: Gender in Chinese Cinema (NanshengNüxiang) [film], London: British Film Institute.

Lim, Song Hwee (2006) Celluloid Comrades: Representations of Male Homosexuality in Contemporary Chinese Cinemas, Honululu: University of Hawai'i Press.

Lim, Song Hwee and Julian Ward (2011) The Chinese Cinema Book, London: BFI.

Lin, Xiaodong et al. (eds) (2016) East Asian Men: Masculinity, Sexuality and Desire, London: Palgrave Macmillan.

Liu, Petrus and Lisa Rofel (eds) (2018) 'Wold Warrior II: The Rise of China and Gender/Sexual Politics', MCLC Resource Centre, http://u.osu.edu/mclc/2018/02/22/wolf-warrior-ii-the-riseof-china-and-gendersexuality-politics/ (accessed 1 November 2018). 
Louie, Kam (2002) Theorising Chinese Masculinity, Cambridge: Cambridge University Press.

Louie, Kam (2008) 'Hero: The return of a Traditional Masculine Ideal in China', in Chris Berry (ed.) Chinese Film in Focus II, London: BFI and Palgrave Macmillan, 137-143.

Louie, Kam (2014) Chinese Masculinities in a Globalising World, London: Routledge.

Lu, Sheldon Hsiao-Peng (1977) Transnational Chinese Cinemas: Identity, Nationhood, Gender, Honululu: University of Hawai'i Press.

Min, Dongchao (2017) Translation and Travelling Theory: Feminist Theory and Praxis in China, London: Routledge.

Mulvey, Laura (1975) 'Visual Pleasure and Narrative Cinema', Screen, 16 (3): 6-18.

Riley, Jo (1997) Chinese Theatre and Actor in Performance, Cambridge: Cambridge University Press.

Robinson, Luke (2013) Independent Chinese Documentary: From the Studio to the Street, London: Palgrave Macmillan.

Robinson, Luke (2015) 'To Whom Do Our Bodies Belong? Being Queer in Chinese DV Documentary', in Zhang Zhen and Angela Zito (eds.) DV-Made China: Digital Subjects and Social Transformations after Independent Cinema, Honululu: University of Hawai'i Press. Rojas, Carlos and Eileen Chow (2014) The Oxford Handbook of Chinese Cinemas, Oxford: Oxford University Press.

Sedgwick, Eve Kosofsky (1985) Between Men: English Literature and Male Homosocial Desire, New York: University of Columbia Press.

Song, Geng (2004) The Fragile Scholar: Power and Masculinity in Chinese Culture, Hong Kong: Hong Kong University Press.

Song, Geng and Derek Hird (2013) Men and Masculinities in Contemporary China, Leiden: Brill.

Voci, Paola and Luo Hui (eds) (2018) Screening China's Soft Power, London: Routledge. Wang, Jing and Tani Barlow (eds) (2002) Cinema and Desire: Feminist Marxism and Cultural Politics in the Works of Dai Jinhua, London: Verso.

Wang, Lingzhen (ed) (2011) Chinese Women's Cinema: Transnational Contexts, New York: Columbia University Press.

Williams, Raymond (1961) The Long Revolution. New York: Penguin. 
Yang, Mayfair Mei-Hui (1999) Spaces of Their Own: Women's Public Sphere in Transnational China, Minneapolis: University of Minnesota Press.

Yu, Sabrina Qiong (2012) Jet Li: Chinese Masculinity and Transnational Film Stardom, Edinburgh: Edinburgh University Press.

Yue, Audrey and Olivia Khoo (2014) Sinophone Cinemas, Basingstoke: Palgrave Macmillan. Zhang, Yingin (2004) Chinese National Cinema, New York: Routledge.

Zhang, Yingjin (2010) Cinema, Space, and Polylocality in a Globalising China, Honululu: University of Hawai'i Press.

Zhang, Yingjin (ed) (2012) A Companion to Chinese Cinema, Chichester: Wily Blackwell. Zhong, Xueping (2000) Masculinity Besieged? Issues of Modernity and Male Subjectivity in

Chinese Literature of the Late Twentieth Century, Durham, NC: Duke University Press.

\footnotetext{
${ }^{1}$ I thank Dr Liu Jieyu for encouraging me to write this chapter and for providing insightful comments and suggestions for various versions of the chapter. This argument for this chapter has been enriched by the lively discussions at the 'Chinese Women's Documentaries in the Market Era' research symposium organised by Professor Wang Lingzhen at Brown University in 2012 and the 'Women Through the Lens: Beyond the Mainstream' panel discussion organised by Lu Xiaoning at SOAS, University of London, in 2018.

2 An 'iron girl' (tie gu'niang) is a term used to refer to young women with a strong will power, an androgynous physical appearance and often a Communist revolutionary conscious. It represented an 'ideal' female subject in the Mao era. For more discussions about the 'iron girl', see Evans 1997 and Yang 1999.
} 